\title{
EDITORIAL
}

\section{Series on comprehensive management of end-stage COPD}

\author{
N. Ambrosino* and R. Goldstein ${ }^{\#}$
}

C hronic obstructive pulmonary disease (COPD) affects $6 \%$ of the general population and is a leading cause of morbidity and mortality worldwide. Severe and very severe disease, as defined by Global Initiative for Chronic Obstructive Lung Disease (GOLD) stages III and IV [1], show a prevalence of 4.5 and $2.2 \%$ in males $[2,3]$. COPD guidelines generally do not address patients with end-stage disease, although such patients are frequently seen in clinical practice by family physicians and respiratory specialists [2, 4]. In the brief series starting in the current issue of the European Respiratory Journal, we review the management of such patients, beginning with the definition, epidemiology and natural history of their condition, as described by VIEGI et al. [5].

End-stage COPD patients have the most severe airflow limitation, the highest levels of dyspnoea and the worst health-related quality of life [6]. Their condition has great impact on their ability to engage in activities and on their participation in social, professional and leisure activities. Their exercise tolerance is markedly reduced by dyspnoea and fatigue, and they have frequent respiratory exacerbations, which often result in hospitalisation. Their gas exchange is usually abnormal, with hypoxaemia requiring supplemental oxygen therapy, and hypercapnia requiring consideration of ventilatory support. These are the patients most likely to experience the worst secondary impairments of COPD, including peripheral muscle, nutritional and psychological dysfunction [7]. Nutritional depletion is a common problem in end-stage COPD, caused by an imbalance between low energy intake and high energy requirements [8], contributing to muscle dysfunction [9] associated with a poor prognosis [10, 11].

These are also the patients most likely to have the largest number of comorbidities, both smoking related and otherwise. Reduced exercise capacity and peripheral muscle dysfunction may be linked by the presence of systemic inflammation [12, 13]. These topics will be addressed in a specific review by FABBRI et al. [14].

\footnotetext{
*Pulmonary Unit, Cardio-Thoracic Dept, University Hospital Pisa, Pisa, Italy. "Dept of Medicine, University of Toronto, Toronto, ON, Canada.
}

STATEMENT OF INTEREST: None declared.

CORRESPONDENCE: N. Ambrosino, U.0. Pneumologia, Dipartimento Cardio-Toracico, Azienda Ospedaliero-Unversitaria Pisana, Via Paradisa 2, Cisanello, 56124 Pisa, Italy. Fax: 3950996779. E-mail: n.ambrosino@ao-pisa.toscana.it
Albert and CALverley [15] will focus on drug therapy (including oxygen) for these patients. Pharmacological therapy for this population is likely to include all three of the main groups, i.e. long-acting $\beta$-agonists, long-acting anti-cholinergics and inhaled corticosteroids, as clinicians attempt to improve airflow and diminish inflammation. Despite the fact that many patients with end-stage disease do not demonstrate reversibility of their forced expiratory volume in one second during pulmonary function testing, some do show an increase in their inspiratory capacity and a diminution of hyperinflation, changes known to be associated with a reduction in dyspnoea and an improvement in exercise capacity. There are few pharmacological studies that specifically address the patient with end-stage disease. However, it is becoming clear that lowdose morphine or other opiates may significantly reduce dyspnoea without significantly accelerating death [16, 17].

Another pharmacological treatment, supplemental oxygen therapy, has been shown in landmark studies to be life saving for those with resting hypoxaemia, an observation that has given rise to domiciliary oxygen programmes around the world.

The more challenging issues in the management of patients with end-stage lung disease relate to the application of oxygen for transient hypoxaemia, at night or during exercise, or the relief of dyspnoea [18, 19]. In addition to the life-saving benefits of long-term oxygen therapy, the use of mechanical ventilatory support, though of vital help as a temporary measure for acute respiratory failure, has yet to be shown to be consistently useful for patients with chronic respiratory failure.

As with most COPD patients who have more than mild disease, management is more effective when pharmacological and nonpharmacological approaches are combined; a topic addressed by AMBrosino and CLINI [20]. To this end, pulmonary rehabilitation has been shown to improve healthrelated quality of life, even amongst the most severe patients [21-23]. There remains a substantial service gap between those likely to benefit from pulmonary rehabilitation and the number of available programmes. This gap is likely to be narrowed by the establishment of community and home-based programmes that emphasise disease self-management and prompt access to professional help when required. Pulmonary rehabilitation is also an important treatment modality for patients with endstage lung disease being considered for lung transplantation. Results of the latter are limited by complications that impair survival, the most important of which is bronchiolitis obliterans [24]. 
As the reader will learn from LACASSE and GOLDSTEIN [25] health-related quality of life is markedly influenced by psychological impairments, whether associated with symptoms of anxiety and depression, commonly identified in patients with COPD, or in the form of a major anxiety or depressive disorder requiring prompt management to enable the patient to function. This is especially noticeable among patients who survive a period of intensive care, in whom anxiety and depression are common and quality of life is poor [26]. Candidates for lung transplantation exhibit a variety of neurocognitive deficits, such as impaired free recall, retrieval deficits and long-term storage [27].

Patients surviving intensive care and requiring long-term mechanical ventilation need detailed discharge planning and homecare services, as described by ESCARRABILL [28]. Only a small proportion of patients with severe COPD discuss end-oflife issues with their physicians, although their reduction in activities of daily living may be similar or worse than patients with nonsmall cell lung cancer [29]. Nevertheless, COPD patients are less likely to receive home nursing and palliative care services than patients with lung cancer, despite having similar preferences for palliation [30,31]. Therapies that are designed to improve comfort and coping become more important than therapies aimed at removing symptoms. There is often a lack of information from professionals regarding diagnosis, prognosis and social support. Impediments to planning end-of-life care, such as not being able to predict prognosis, in the setting of a gradual decline punctuated by episodic exacerbations result in difficult decisions being deferred, so that few patients complete advance directives [32]. Decision aids can increase knowledge, realistic perceptions of benefit and harm from interventions, and can improve agreement between the patient's reported values and the option that is chosen [33].

Advance directives increase patient autonomy by their specifying treatment choices and indicating surrogate decision makers [34]. Patients educated in advance directives are more likely to be assured that the physicians understand their preferences [35] and patients with-end stage chronic obstructive pulmonary disease will raise these issues if prompted to do so [36]. This important issue, and also other ethical and legal issues, will be addressed by CURTIS [37].

\section{REFERENCES}

1 Global Initiative for Chronic Obstructive Lung Disease. Workshop report, global strategy for diagnosis, management, and prevention of COPD. Update Sept 2005. Bethesda, National Institutes of Health, National Heart, Lung and Blood Institute; 2005. Available from: www.goldcopd.com.

2 Ambrosino N, Simonds A. The clinical management in extremely severe COPD. Respir Med 2007; 101: 1613-1624.

3 Zielinski J, Bednarek M, Górecka D, et al. Increasing COPD awareness. Eur Respir J 2006; 27: 833-852.

4 Celli BR, MacNee W, ATS/ERS Task Force, Standards for the diagnosis and treatment of patients with COPD: a summary of the ATS/ERS position paper. Eur Respir J 2004; 23: 932-946.
5 Viegi G, Pistelli F, Sherrill DL, Maio S, Baldacci S, Carrozzi L. Definition, epidemiology and natural history of COPD. Eur Respir J 2007; 30: 993-1013.

6 Simonds AK. Care of end stage lung disease. Breathe 2006; 4: 315-320.

7 Agustí AGN. Systemic effects of chronic obstructive pulmonary disease. Proc Am Thorac Soc 2005; 2: 367-370.

8 Debigaré R, Côté $\mathrm{CH}$, Maltais F. Peripheral muscle wasting in chronic obstructive pulmonary disease. Am J Respir Crit Care Med 2001; 164: 1712-1717.

9 Wouters EFM. Chronic obstructive pulmonary disease. 5: systemic effects of COPD. Thorax 2002; 57: 1067-1070.

10 Anthonisen NR, Wright EC, Hodgkin JE. Prognosis in chronic obstructive pulmonary disease. Am Rev Respir Dis 1986; 133: 14-20.

11 Schols AM, Slangen J, Volovics L, Wouters EFM. Weight loss is a reversible factor in the prognosis of chronic obstructive pulmonary disease. Am J Respir Crit Care Med 1998; 157; 1791-1797.

12 Pinto-Plata VM, Müllerova $\mathrm{H}$, Toso JF, et al. C-reactive protein in patients with COPD, control smokers and nonsmokers. Thorax 2006; 61: 23-28.

13 Koechlin C, Maltais F, Saey D, et al. Hypoxaemia enhances peripheral muscle oxidative stress in chronic obstructive pulmonary disease. Thorax 2005; 60: 834-841.

14 Fabbri LM, Luppi F, Beghè B, Rabe KF. Metabolic and systemic effects. Eur Respir J 2007; (In Press).

15 Albert P, Calverley PMA. Drug therapy (including oxygen). Eur Respir J 2007; (In Press).

16 Poole PJ, Veale AG, Black PN. The effect of sustainedrelease morphine on breathlessness and quality of life in severe chronic obstructive pulmonary disease. Am J Respir Crit Care Med 1998; 157: 1877-1880.

17 Abernethy AP, Currow DC, Frith P, Fazekas BS, McHugh A, Bui C. Randomised, double blind, placebo controlled crossover trial of sustained release morphine for the management of refractory dyspnoea. BMJ 2003; 327: 523-528.

18 Palange $\mathrm{P}$, Crimi E, Pellegrino R, Brusasco V. Supplemental oxygen and heliox: 'new' tools for exercise training in chronic obstructive pulmonary disease. Curr Opin Pulm Med 2005; 11: 145-148.

19 O'Donnell DE, D'Arsigny C, Webb KA. Effects of hyperoxia on ventilatory limitation during exercise in advanced chronic obstructive pulmonary disease. Am J Respir Crit Care Med 2001; 163: 892-898.

20 Ambrosino N, Clini E. Nonpharmacological treatment and relief of symptoms. Eur Respir J 2007; (In Press).

21 Nici L, Donner C, Wouters E, et al. American Thoracic Society/European Respiratory Society statement on pulmonary rehabilitation. Am J Respir Crit Care Med 2006; 173: 1390-1413.

22 Ries AL, Bauldoff GS, Carlin BW, et al. Pulmonary Rehabilitation. Joint ACCP/AACVPR Evidence-Based Clinical Practice Guidelines. Chest 2007; 131: Suppl. 5, 4S-42S.

23 Cote CG, Celli BR. Pulmonary rehabilitation and the BODE index in COPD. Eur Respir J 2005; 26: 630-636.

24 Martinez FJ, Chang A. Surgical therapy for chronic obstructive pulmonary disease. Semin Respir Crit Care Med 2005; 26: 167-191.

25 Lacasse Y, Goldstein R. Health status and psychological effects. Eur Respir J 2007; (In Press). 
26 Hopkins RO, Weaver LK, Collingridge D, Parkinson RB, Chan KJ, Orme JF Jr. Two-year cognitive, emotional, and quality-of-life outcomes in acute respiratory distress syndrome. Am J Respir Crit Care Med 2005; 171: 340-347.

27 Crews WD, Jefferson AL, Bolduc T, et al. Neuropsychological dysfunction in patients suffering from end-stage chronic obstructive pulmonary disease. Arch Clin Neuropsychol 2001; 16: 643-652.

28 Escarrabill J. Discharge planning and home care. Eur Respir J 2007; (In Press).

29 Gore JM, Brophy CJ, Greenstone MA. How well do we care for patients with end stage chronic obstructive pulmonary disease (COPD)? A comparison of palliative care and quality of life in COPD and lung cancer. Thorax 2000; 55: 1000-1006.

30 Connors AF Jr, Dawson NV, Thomas C, et al. Outcomes following acute exacerbation of severe chronic obstructive lung disease. The SUPPORT investigators (Study to Understand Prognoses and Preference for Outcomes and Risks of Treatment). Am J Respir Crit Care Med 1996; 154: 959-967.

31 Claessens MT, Lynn J, Zhong Z, et al. Dying with lung cancer or chronic obstructive pulmonary disease: insights from SUPPORT. Study to Understand Prognoses and Preferences for Outcomes and Risks of Treatments. J Am Geriatr Soc 2000; 48: Suppl. 5, S146-S153.

32 Elkington $\mathrm{H}$, White $\mathrm{P}$, Addington-Hall J, Higgs R, Edmonds P. The healthcare needs of chronic obstructive pulmonary disease patients in the last year of life. Palliat Med 2005; 19: 485-491.

33 Dales RE, O'Connor A, Hebert P, Sullivan K, McKim D, Llewellyn-Thomas $\mathrm{H}$. Intubation and mechanical ventilation for COPD. Development of an instrument to elicit patient preferences. Chest 1999; 116: 792-800.

34 Hahn ME. MSJAMA. Advance directives and patientphysician communication. JAMA 2006; 289: 96.

35 Heffner JE, Fahy B, Hilling L, Barbieri C. Outcomes of advance directive education of pulmonary of pulmonary rehabilitation patients. Am J Respir Crit Care Med 1997; 155: 1055-1059.

36 Curtis JR, Wenrich MD, Carline JD, Shannon SE, Ambrozy DM, Ramsey PG. Patients' perspectives on physician skill in end-of-life care. Differences between patients with COPD, cancer and AIDS. Chest 2002; 122 356-362.

37 Curtis JR. Ethical and legal issues. Eur Respir J 2007; (In Press). 